\title{
PENGAMBILAN KEPUTUSAN MENJADI PEKERJA MIGRAN INDONESIA PEREMPUAN
}

\section{THE DECISION MAKING OF INDONESIAN WOMAN MIGRANT WORKER}

\author{
Nurul Aeni \\ Badan Perencanaan Pembangunan Daerah Kabupaten Pati \\ Jl. Raya Pati-Kudus Km. 4 Pati. 59163. Jawa Tengah
}

\begin{abstract}
Decision of being woman migrant workers brings both positive and negative consequeces for the woman workers as well as their families live behind. This study aimed: (1) to describe the decision making of being migrant workers among the applicants of woman migrant workers from Pati District; (2) to explain the factors correlate to the migrate decision making, and (3) to explain factors correlate to destination country choosing. It used quantitave approach. The primary data were obtained by spreading questionnaires among women migrant worker applicants at four labour supply companies. Meanwhile the secondary data get through desk review. Then, the data were analysed descriptively using chi square and correspondence analysis. The study resulted: (1) economic was the main factor of decision making for being woman migrant workers; (2) the factors correlated to the decision making for being woman migrant workers were the position in household, previous income, and decision making process; (3) high salary was the main factor on choosing the destination country. The factors correlated to destination country preferences were: the reasons for choosing the destination countries, age, previous job, previous salary, and husband's age.
\end{abstract}

Keywords: decision making, migrant worker, women.

\begin{abstract}
ABSTRAK
Keputusan menjadi pekerja migran perempuan dapat berkonsekuensi positif maupun negatif bagi pekerja migran maupun keluarga yang ditinggalkan. Penelitian ini bertujuan: (1) menggambarkan pengambilan keputusan menjadi pekerja migran perempuan pada calon pekerja migran di Kabupaten Pati; (2) mendeskripsikan faktor yang berhubungan dengan pengambilan keputusan; dan (3) mendeskripsikan faktor yang berhubungan dengan pemilihan negara tujuan. Penelitian menggunakan pendekatan kuantitatif. Data primer didapatkan melalui pengisian kuesioner oleh para calon pekerja migran perempuan di empat PPTKIS. Sementara data sekunder didapatkan melalui review penelitian terdahulu dan dokumen yang relevan. Data yang diperoleh dianalisis secara deskriptif menggunakan chi square dan analisis korespondensi. Hasil penelitian adalah: (1) ekonomi adalah faktor utama pengambilan keputusan menjadi pekerja migran perempuan; (2) faktor yang berhubungan dengan pengambilan keputusan menjadi pekerja migran adalah posisi dalam rumah tangga, pendapatan sebelumnya, dan proses pengambilan keputusan; (3) gaji yang tinggi merupakan alasan utama pemilihan negara tujuan migrasi. Adapun faktor yang berhubungan dengan pemilihan negara tujuan migrasi adalah alasan pemilihan negara, usia, pekerjaan sebelumnya, pendapatan sebelumnya, dan usia suami.
\end{abstract}

Kata kunci: pengambilan keputusan, pekerja migran, perempuan

\section{PENDAHULUAN}

International Labour Migration atau ILO menyatakan terjadi peningkatan jumlah pekerja migran di tahun 2017 sebesar 9\% dari jumlah pekerja migran tahun 2015 dimana konsentrasi tertinggi berada di negara dengan penghasilan tinggi (ILO, 2018). Selanjutnya, beberapa negara menjadi pengirim utama pekerja migran, seperti Indonesia. Badan Nasional Penempatan dan Perlindungan Tenaga Kerja Indonesia (BNP2TKI) melaporkan hingga tahun 2018, terdapat sekitar 3,65 juta pekerja migran Indonesia (PMI) yang tersebar di berbagai negara dengan persentase tertinggi berada di Negara Malaysia, Hongkong, serta Taiwan (BNP2TKI, 2019). Keberadaan pekerja 
migran telah terbukti berkontribusi terhadap pembangunan di negara asal pekerja. Bentuk kontribusinya melalui pengiriman remitan. Kontribusi remitan terhadap pembangunan dapat dilihat dari aspek makro maupun mikroekonomi. Secara makro, remitan terbukti mampu meningkatkan Pendapatan Domestik Bruto (PDB), bahkan menjadi salah satu sumber pendapatan utama (Barai, 2012; De Haas, 2010; Guha, 2013; Khan et al., 2015). Kondisi yang sama juga terjadi di Indonesia. Pengiriman remitan oleh para pekerja migran Indonesia terus mengalami peningkatan setiap tahunnya. Tahun 2018, pengiriman remitan mencapai 11 milyar USD dan menjadi sumber pendapatan negara terbesar dari sektor nonmigas (Bank Indonesia, 2018).

Selain peningkatan $\mathrm{PDB}$, pengiriman remitan juga berperan terhadap penurunan kemiskinan. Menurut Chan (2014) beberapa negara, terutama negara berkembang memanfaatkan pengiriman pekerja migran sebagai strategi temporal untuk mengatasi kemiskinan. Sebuah studi menyatakan bahwa keberadaan pekerja migran di Nepal mampu menurunkan kemiskinan hingga 20\% (Lokshin et al., 2010). Kontribusi pekerja migran terhadap pengurangan kemiskinan dapat dijelaskan melalui kontribusi remitan pada tataran mikro. Remitan yang dikirimkan kepada keluarga di negara asal pada umumnya digunakan untuk pemenuhan kebutuhan dasar, seperti pangan dan sandang. Hasilnya, kesejahteraan keluarga meningkat sehingga keluarga tersebut mampu keluar dari kemiskinan (Guha, 2013)

Sebagaimana dua sisi mata uang, keputusan menjadi pekerja migran tidak hanya berdampak secara positif, namun juga berpotensi mendatangkan konsekuensi negatif. Konsekuensi negatif tersebut lebih mungkin terjadi pada pekerja migran perempuan dibandingkan pekerja migran laki-laki. Para pekerja migran perempuan khususnya dengan kualifikasi pendidikan rendah, pada umumnya bekerja di sektor domestik yang memiliki kerentanan tinggi akibat posisi tawar yang rendah (IOM, 2010). BNP2TKI melaporkan bahwa lebih dari 70\% PMI merupakan pekerja perempuan yang sebagian besar bekerja di sektor domestik. Selanjutnya, sebagian dari pekerja tersebut dilaporkan mengalami permasalahan seperti gaji yang lebih rendah dari perjanjian kerja, beban kerja yang berlebih, serta kekerasan baik fisik, psikologis, dan seksual (BNP2TKI, 2019).

Keputusan perempuan menjadi pekerja migran juga kemungkinan mempengaruhi kesejahteraan psikologis anggota keluarga yang ditinggalkan. Kepergiaan anggota keluarga untuk bermigrasi dipastikan merubah struktur keluarga. Kondisi tersebut memicu fenomena yang disebut sebagai grandmothering (Sijapati, 2015). Fenomena tersebut merujuk pada perubahan dinamika pengasuhan anak keluarga yang ditinggalkan. Ketika ibu menjadi pekerja migran maka peran pengasuhan selanjutnya dilimpahkan kepada anggota keluarga besar lainnya yang juga perempuan (biasanya nenek). Selain itu, ketidaksiapan anak berpisah dengan ibu seringkali memunculkan kesenjangan komunikasi yang selanjutnya menjadi sumber ketidakpuasan dan perasaan negatif pada anak (Hoang \& Yeoh, 2012).

Merujuk adanya dampak positif dan negatif dari menjadi pekerja migran, pengambilan keputusan bekerja di luar negeri terutama pada perempuan pada dasarnya merupakan proses yang kompleks karena melibatkan berbagai faktor. Namun demikian, faktor ekonomi tetap dianggap sebagai determinan utama penentu pengambilan keputusan menjadi pekerja migran. Asriani \& Amalia (2016) menyatakan bahwa kemiskinan dan kelangkaan sumber daya ekonomi di daerah asal menjadikan migrasi sebagai alternatif yang diambil guna mendapatkan penghasilan. Sementara itu, permintaan akan pekerja migran didominasi oleh sektor domestik membuat kesempatan untuk perempuan lebih terbuka. Penelitian lain menyebutkan bahwa semakin tinggi proporsi kemiskinan di suatu wilayah cenderung meningkatkan jumlah pekerja migran perempuan di wilayah tersebut (Aeni, 2017). Perkembangan teknologi dan informasi yang begitu pesat kemungkinan juga berpengaruh terhadap motivasi bekerja di luar negeri. Terdapat alasan 
lain menjadi pekerja migran, seperti kesempatan mendapatkan pengalaman baru, belajar bahasa asing, serta melanjutkan pendidikan juga dapat menjadi motivasi bekerja di luar negeri (Iqbal \& Gusman, 2015).

Menurut BNP2TKI (2019) Jawa Tengah adalah propinsi pengirim pekerja migran terbanyak setelah Jawa Timur. Pengiriman pekerja migran dari Jawa Tengah di tahun 2018 mencapai $21,66 \%$ dari total pengiriman pekerja migran Indonesia. Selanjutnya, Kabupaten Pati adalah satu di antara kabupaten pengirim pekerja migran terbanyak setelah Kabupaten Cilacap, Kendal, Brebes, dan Banyumas. Jumlah penduduk Kabupaten Pati yang bekerja di luar negeri mengalami fluktuasi periode tahun 2014 -2016 dengan jumlah tertinggi terjadi di tahun 2016 (Aeni, 2017). Jumlah pekerja perempuan juga mengalami pertumbuhan dengan persentase sebesar $24 \%$ di tahun 2016. Selanjutnya, Taiwan adalah negara tujuan utama para pekerja migran perempuan dari Kabupaten Pati dengan pekerjaan yang dipilih sebagian besar di sektor domestik sebagai asisten rumah tangga atau perawat Lansia.

Keberadaan pekerja migran di Kabupaten Pati telah terbukti mampu meningkatkan kesejahteraan ekonomi keluarga yang ditinggalkan, penciptaan lapangan pekerjaan serta pemberdayaan masyarakat daerah asal (Dibyantoro \& Alie, 2014). Namun demikian, pengambilan keputusan menjadi pekerjaan migran perempuan juga dibayangi konsekuensi negatif yang mungkin saja terjadi pada dirinya atau keluarga yang ditinggalkan. Penelitian terhadap anak pekerja migran di Kabupaten Pati menyimpulkan bahwa anak pekerja migran cenderung memiliki skor kecerdasan emosi yang lebih rendah dibandingkan anak dari ibu non-pekerja migran (Aeni, 2011). Berdasarkan latar belakang tersebut, tujuan penelitian ini adalah: (1) menggambarkan pengambilan keputusan menjadi pekerja migran perempuan; (2) mendeskripsikan faktor-faktor yang berhubungan dengan pengambilan keputusan menjadi pekerja migran; dan (3) mendeskripsikan faktorfaktor yang berhubungan dengan pemilihan negara tujuan migrasi.

\section{TINJAUAN PUSTAKA}

\section{Pekerja Migran Perempuan}

Definisi pekerja migran perempuan pada studi ini dibatasi hanya pada pekerja migran perempuan yang bekerja di luar negeri. Migrasi internasional dapat didefinisikan sebagai perpindahan negara sebagai tempat tinggal. Ada batasan waktu untuk dapat mengkategorikan perpindahan negara sebagai migrasi. Migrasi jangka pendek adalah perpindahan negara yang terjadi pada rentang waktu tiga bulan hingga satu tahun, sementara lebih dari satu tahun disebut sebagai migrasi jangka panjang (ILO, 2018).

Salah satu tujuan migrasi adalah untuk memperoleh penghasilan yang disebut sebagai pekerja migran. Pekerja migran dapat diartikan sebagai seseorang yang berpindah dari negara asalnya ke negara lain untuk tujuan bekerja (IOM, 2010). Berdasarkan laporan ILO (2018), pada tahun 2017 terdapat sekitar 164 juta pekerja migran yang tersebar di berbagai negara. Jumlah tersebut mencakup lebih dari 59\% dari total migran. Jumlah pekerja migran di tahun tersebut mengalami peningkatan sekitar 9\% dari jumlah pekerja migran di tahun 2013.

Terjadi perubahan untuk penyebutan istilah pekerja migran di Indonesia. Hingga tahun 2017, istilah yang digunakan adalah Tenaga Kerja Indonesia (TKI). Setelahnya, istilah yang digunakan adalah Pekerja Migran Indonesia (PMI). Selain kedua istilah tersebut juga dikenal Buruh Migran Indonesia (BMI). Undang -Undang No. 18 Tahun 2017 mendefinisikan PMI sebagai setiap warga negara Indonesia yang akan, sedang, atau telah melakukan pekerjaan dengan menerima upah di luar wilayah Republik Indonesia (UU No. 18 Tahun 2017).

Krisis ekonomi yang terjadi sekitar tahun 2008 menyebabkan terjadinya peningkatan pengiriman pekerja migran Indonesia. Lebih lanjut, pekerja yang dikirim sebagian besar adalah pekerja perempuan hingga memunculkan fenomena feminisasi migrasi. Istilah tersebut merujuk kepada meningkatnya permintaan pekerja migran perempuan di beberapa negara 
maju terutama di negara Kawasan Asia Timur. Hal tersebut dipicu oleh meningkatnya jumlah perempuan yang bekerja di ranah publik, sehingga mereka harus mencari pekerja untuk menggantikan peran mereka di ranah domestik. Pekerjaan di sektor domestik identik dengan perempuan yang menyebabkan permintaan pekerja migran di sektor ini didominasi oleh pekerja perempuan (Hoang, 2009).

ILO (2018) melaporkan secara global persentase pekerja migran perempuan lebih rendah dibandingkan pekerja migran laki-laki. Selain itu, terjadi kecenderungan penurunan persentase pekerja migran perempuan periode 2013-2017. Kondisi tersebut berbeda dengan yang terjadi di Indonesia. PMI didominasi oleh perempuan (sekitar 70\%) dengan persentase yang cenderung meningkat setiap tahunnya dan terkonsentrasi di sektor domestik (BNP2TKI, 2019). Menurut Chen (2011), pekerja sektor domestik pada umumnya bekerja untuk keluarga atau perorangan. Oleh karenanya, mereka cenderung memiliki pengetahuan yang mendalam serta personal tentang pihak dimana mereka bekerja, namun seringkali disertai pola hubungan yang tidak setara. Sebagai akibatnya, pekerja di sektor domestik rentan mengalami diskriminasi bahkan kekerasan (ILO, 2018).

\section{Pengambilan Keputusan menjadi Pekerja Migran}

Penjelasan mengenai faktor penyebab migrasi beragam, tergantung pada keluasan analisis yang digunakan. Menurut Hagen-Zaker (2008), secara umum analisis mengenai migrasi dapat dibedakan dalam tiga level, yaitu makro, meso, dan mikro. Sementara itu, dalam penelitian ini fokus analisis pengambilan keputusan menjadi pekerja migran dibatasi pada level meso dan mikro.

Beberapa ahli menganggap pengambilan keputusan melakukan migrasi pada dasarnya bukan lah keputusan yang diambil secara individu melainkan juga melibatkan keluarga (meso level). Salah satu model yang menggunakan pendekatan ini adalah model New Economic Labour Migration (NELM). Menurut model ini, keputusan melakukan migrasi merupakan dari bagian dari strategi yang diambil bersama oleh keluarga untuk memperoleh penghasilan dalam bentuk remitan. Remitan tersebut selajutnya menjadi jaminan bagi keluarga di negara asal untuk membiayai aktivitas mereka serta melindungi keluarga tersebut dari risiko kehilangan capital ketika mengalami kegagalan dalam aktivitas ekonomi. Kontribusi remitan adalah faktor yang membedakan model ini dengan model migrasi yang lain. Namun demikian, pembahasan mengenai remitan tidak bisa dilepaskan dari sumber pendapatan keluarga yang lain. Pola migrasi keluarga dengan beberapa sumber pendapatan mungkin saja berbeda dengan pola migrasi keluarga yang hanya mendapatkan pendapatan dari remitan (Taylor, 1999).

Pendekatan analisis migrasi selanjutnya adalah pada level mikro. Terdapat beberapa pendekatan yang dapat digunakan untuk menjelaskan migrasi pada level mikro. Teori migrasi pertama adalah neoklasikal yang menitiberatkan pada aspek ekonomi dan geografi. Model migrasi yang menggunakan pendekatan ini adalah Dorong-Tarik (Push-Pull) oleh Lee (1966) dan Human-Capital oleh (Sjaastad, 1962). Menurut model Push-Pull, terdapat seperangkat faktor di daerah asal dan daerah tujuan yang kemudian oleh individu dimaknai positif sebagai penarik dan negatif sebagai pendorong. Pemaknaan seperangkat faktor tersebut akan berbeda antara individu satu dengan individu lainnya bergantung kepada faktor personal maupun siklus kehidupan yang dimiliki oleh individu tersebut. Diantara faktor penarik dan pendorong, terdapat faktor penghubung dan faktor penghambat, seperti jarak, hambatan yang bersifat fisik, serta hukum dan kebijakan mengenai migrasi yang juga mempengaruhi pengambilan keputusan melakukan migrasi.

Teori neoklasikal selanjutnya adalah model Human-Capital oleh Sjaastad (1962). Sementara model Push-Pull menitikberatkan kepada faktor geografis, model Human-Capital berfokus kepada aspek ekonomi. Berdasarkan model tersebut, migrasi dilihat sebagai bentuk investasi dalam rangka meningkatkan produktivitas sumber daya manusia. Sebagai sebuah 
investasi, keputusan untuk melakukan migrasi didasarkan pada penghitungan biaya yang dikeluarkan serta keuntungan yang akan akan didapatkan. Penghitngan biaya dan keuntungan dipengaruhi oleh faktor personal, seperti usia, pendidikan, pengalaman kerja, dan jenis kelamin. Semakin rendah biaya yang dikeluarkan dan semakin tinggi keuntungan yang akan didapat meningkatkan kemungkinan individu melakukan migrasi.

Teori migrasi selanjutnya menggunakan pendekatan perilaku, yaitu model ValueExpectancy atau Nilai-Harapan oleh De Jong \& Fawcett (1981). Model perilaku ini sebenarnya berakar dari model perilaku beralasan (Theory of Reasoned Action/TRA) dari Azjen dan Fishbein (De Jong et al., 1986). Berdasarkan model perilaku, sebuah perilaku selalu didahului oleh niatan atau intensi. Intensi atau motif untuk melakukan migrasi dapat beragam dari yang berlatar belakang ekonomi, sosial, hingga geografis. Intensi melakukan migrasi dapat didefinisikan sebagai total dari nilai dan harapan. Nilai dapat diartikan sebagai tujuan yang ingin dicapai. Adapun harapan adalah kepercayaan/kemungkinan subjektif bahwa suatu perilaku akan mendatangkan suatu hasil tertentu. Harapan dipengaruhi oleh informasi yang diperoleh individu, bagaimana informasi tersebut disaring, dipersepsikan, dan divalidasi. Terbentuknya nilai dan harapan juga dipengaruhi oleh kondisi demografis individu dan keluarga, norma sosial-budaya, kepribadian pribadi, dan struktur kesempatan yang tersedia. Walaupun model nilai-harapan termasuk dalam model mikro, namun demikian bukan berarti keluarga serta lingkungan tidak memberikan pengaruh. Dapat dikatakan bahwa model ini merupakan integrasi antara level individu, level rumah tangga, serta determinan sosial.

Berdasarkan ketiga model migrasi yang dipaparkan, penelitian ini akan memfokuskan analisis berdasarkan pendekatan NilaiHarapan. Hal tersebut didasarkan pada alasan bahwa model tersebut menganggap pengambilan keputusan sebagai keputusan pribadi. Namun demikian, sebagai keputusan individu, model tetap memperhatikan peran keluarga dan lingkungan (teman) dalam memformulasikan motif yang mendasari pengambilan keputusan melakukan migrasi. Selain itu, model tersebut tidak hanya fokus kepada motif ekonomi yang oleh sebagian model migrasi mendapatkan porsi yang cukup besar.

\section{METODE PENELITIAN}

Penelitian menggunakan pendekatan kuantitatif. Pendekatan tersebut digunakan untuk menganalisis data yang berasal dari kuesioner. Menggunakan sudut pandang yang lain, penelitian ini menggunakan metode deskriptif dengan cara menganalisis dan menyajikan temuan penelitian secara sistematis sehingga mudah dipahami.

Data yang digunakan berupa data sekunder dan primer. Data sekunder didapatkan melalui observasi data calon tenaga pekerja migran dari Dinas Tenaga Kerja dan Transmigrasi (Disnakertrans) Kabupaten Pati serta review beberapa penelitian terdahulu. Sementara data primer diperoleh melalui pengisian kuesioner oleh calon pekerja migran perempuan yang tersebar di empat Perusahaan Penyalur Tenaga Kerja Indonesia Swasta (PPTKIS) yang berada di Kabupaten Pati, yaitu PT. Dewi Pengayom Bangsa, PT. Pelita Karya Juhari, PT. Arni Family, dan PT. Bela Sukses Makmur.

Kuesioner penelitian berisi variabel penelitian yaitu karakteristik demografi calon pekerja migran perempuan dan suami, seperti usia, pendidikan, pekerjaan sebelum menjadi calon PMI, pendapatan, pengalaman menjadi PMI, negara tujuan, sumber informasi tentang PMI, proses pengambilan keputusan menjadi PMI, alasan menjadi PMI, alasan pemilihan negara tujuan, serta rencana penggunaan remittance. Sebagian besar pertanyaan berjenis semi terbuka dimana peneliti menyediakan beberapa pilihan jawaban, namun tetap memberikan kesempatan kepada responden untuk memberikan jawaban yang berbeda.

Jumlah responden yang terlibat dalam pengambilan data berjumlah 220 calon pekerja migran perempuan. Namun demikian dalam pengolahan data, hanya 197 kuesioner yang 
memenuhi persyaratan untuk diolah lebih lanjut karena beberapa diantaranya berasal dari luar Kabupaten Pati. Adapun persebaran responden di setiap PPTKIS berbeda bergantung kepada jumlah calon pekerja migran yang sedang mengikuti pelatihan di PPTKIS tersebut. Persentase responden terbesar berada di PT. Pelita Karya Juhari (42,64\%), disusul oleh PT. Dewi Pengayom Bangsa (35,53\%), PT. Bela Sukses Mandiri (18,78\%), dan PT. Arny Family (3,05\%).

Pengolahan data menggunakan analisis deskriptif, baik univariat, bivariat, dan multivariat. Analisis univariat digunakan utuk meringkas data dalam bentuk tabel ataupun grafik. Sementara itu, analisis bivariat, yaitu chi-square digunakan untuk menguji korelasi variabel bebas dengan variabel terikat, yaitu alasan utama melakukan migrasi dan pemilihan negara tujuan migrasi. Data dari kedua jenis variabel merupakan data nominal. Hasil uji chi-square yang menunjukkan hubungan bermakna selanjutnya diuji secara multivariat menggunakan analisis korespondensi. Menggunakan analisis korespondensi, data direduksi menjadi lebih sederhana dengan mengabungkan kategori yang memiliki kesamaan dalam satu variabel (Saefuloh, 2016). Hasil analisis korespondensi selanjutnya ditampilkan dalam sebuah grafik kontingensi. Titik-titik pada variabel kolom dan variabel baris yang saling berdekatan dianggap memiliki hubungan yang signifikan.

\section{HASIL DAN PEMBAHASAN}

Rentang usia responden saat pengisian kuesioner adalah 21-43 tahun. Sebagian besar responden berada pada rentang usia 21-30 tahun $(57,9 \%)$ dan hanya sekitar $2,5 \%$ responden yang berada pada rentang usia $>40$ tahun. Berdasarkan tingkat pendidikan, sebagian besar responden berpendidikan setingkat SMP atau lebih rendah $(73,1 \%)$. Berdasarkan status pernikahan, sebagian besar responden $(80,7 \%)$ telah menikah, $16,2 \%$ berstatus sebagai janda, dan hanya sekitar 3\% berstatus belum menikah. Sebagian besar responden (58,9\%) menyatakan belum pernah menjadi pekerja migran sebelumnya dan sekitar $17 \%$ responden menyatakan pernah lebih dari satu kali menjadi pekerja migran. Berdasarkan status pekerjaan sebelumnya, sebagian besar responden adalah ibu rumah tangga $(58,9 \%)$ dan $34 \%$ responden diantaranya merupakan pekerja swasta.

Responden penelitian berasal dari seluruh kecamatan di Kabupaten Pati dengan frekuensi berbeda. Kecamatan dengan jumlah responden terbanyak adalah Kayen dan Gabus dengan persentase masing-masing 10,7\%. Kecamatan Sukolilo, Cluwak, dan Pucakwangi juga memiliki persentase yang tinggi, yaitu masing-masing 10,2\%, 8,1\%, dan 8,1\%. Pembahasan hasil penelitian terbagi dalam tiga subpembahasan, yaitu gambaran pengambilan keputusan menjadi pekerja migran, faktor pengambilan keputusan menjadi Pekerja $\mathrm{Mi}$ gran Indonesia (PMI), dan faktor yang mempengaruhi pemilihan negara tujuan migrasi.

\section{Gambaran Pengambilan Keputusan Menjadi Pekerja Migran}

Pengujian deskriptif menunjukkan bahwa faktor ekonomi menjadi alasan utama yang melatarbelakangi pengambilan keputusan menjadi pekerja migran $(79,6 \%)$. Tingkat kesejahteraan ekonomi yang rendah merupakan faktor pendorong utama tingginya tingkat migrasi. Hal tersebut dapat dipicu dari kualitas fisik lingkungan yang buruk serta kepadatan penduduk yang tinggi. Kondisi tersebut meningkatkan persaingan dalam memperoleh pendapatan. Oleh karenanya, melakukan migrasi merupakan salah satu strategi rasional yang dipilih untuk memperoleh pendapatan (Wafirotin, 2016) .

Mengacu kepada model Nilai-Harapan, migrasi tidak hanya ditentukan oleh faktor tunggal, melainkan kombinasi dari beberapa faktor. Hal tersebut terkonfirmasi melalui hasil penelitian ini. Mayoritas responden (86,29\%) menyatakan memiliki dua atau lebih alasan yang melatarbelakangi pengambilan keputusan menjadi pekerja migran. Gambaran faktor yang mendasari pengambilan keputusan menjadi pekerja migran ditampilkan pada Tabel 1. 
Jurnal Litbang Vol. XV No. 2 Bulan Desember 2019 Hal 107-120

Tabel 1.

Alasan Pengambilan Keputusan Menjadi Pekerja Migran

\begin{tabular}{lrr}
\hline \multicolumn{1}{c}{ Alasan } & $\begin{array}{c}\text { N Responden } \\
\text { (org) }\end{array}$ & \multicolumn{2}{c}{$\begin{array}{c}\text { Persentase } \\
\text { (\%) }\end{array}$} \\
\hline Mendapat Penghasilan & 189 & 95,9 \\
Tidak Tersedia Pekerjaan & 47 & 23,9 \\
Menghindari Pandangan Negatif Masyarakat & 12 & 6,1 \\
Mendapatkan Pengalaman Baru & 144 & 73,1 \\
Lain-lain & 10 & 5,1 \\
\hline
\end{tabular}

Berdasarkan Tabel 1 dapat dinyatakan bahwa pengambilan keputusan menjadi pekerja migran tidak hanya didasarkan pada alasan ekonomi (mendapatkan penghasilan). Para responden juga menjadikan bekerja di luar negeri sebagai media untuk mendapatkan pengalaman baru $(73,1 \%)$. Hasil temuan penelitian ini selaras dengan hasil penelitian oleh Iqbal \& Gusman (2015) yang menyatakan adanya pergesaran dinamika migrasi. Para pekerja migran terutama yang masih berusia muda dan juga belum menikah cenderung tidak menempatkan ekonomi sebagai alasan untuk melakukan migrasi melainkan mendapatkan pengalaman baru. Selain itu tidak tersedianya pekerjaan di daerah asal juga menjadi alasan pengambilan keputusan menjadi pekerja migran. Keadaan tidak tersedianya pekerjaan di suatu wilayah selanjutnya akan meningkatkan tingkat pengangguran di wilayah tersebut. Pengiriman tenaga kerja ke luar negeri diambil sebagai salah satu strategi untuk mengurangi jumlah pengangguran (Puspitasari \& Kusreni, 2017). Sementara itu, negara-negara maju sebagai penerima tenaga kerja mengalami peningkatan jumlah penduduk lanjut usia serta angkatan kerja perempuan. Sebagai akibatnya, terjadi penurunan jumlah perempuan yang terlibat di sektor domestik yang diikuti oleh peningkatan permintaan pekerja migran di sektor tersebut. Pekerjaan pada sektor domestik identik dengan perempuan serta tidak membutuhkan kualifikasi pendidikan tertentu (Hoang et al., 2012).

Negara-negara di Kawasan Asia Timur dan Tenggara merupakan tujuan utama para responden. Taiwan menjadi pilihan sebagian besar responden (53,3\%). Selain Taiwan, Hongkong juga dipilih oleh sekitar 25,9\% dan Singapura dipilih oleh $18,3 \%$ responden sebagai negara tujuan. Adapun Malaysia merupakan negara yang paling sedikit diminati oleh responden dengan persentase sebesar 2,5\%.

Model Nilai-Harapan menyatakan bahwa keluarga memegang peranan penting dalam pengambilan keputusan untuk melakukan migrasi. Hal tersebut dibuktikan dalam penelitian ini yang menyatakan bahwa sekitar $51,3 \%$ pengambilan keputusan dilakukan bersama dengan keluarga, terutama keluarga inti (bersama dengan suami dan anak). Hal yang menarik adalah keterlibatan keluarga besar dalam pengambilan keputusan sebagaimana dinyatakan oleh $43,1 \%$ responden. Sebagian besar responden memiliki anak yang masih membutuhkan pengasuhan. Keputusan menjadi pekerja migran selanjutnya diikuti konsekuensi pelimpahan tanggung jawab pengasuhan anak yang pada umumnya berpindah kepada keluarga besar. Sebagai akibatnya, calon pekerja perempuan merasa perlu melibatkan keluarga besar dalam mengambil keputusan apalagi yang nantinya akan terlibat dalam pengasuhan anak (Hoang et al., 2012). Keluarga yang terlibat dalam pengasuhan anak selama ditinggal ibu pada umumnya berasal dari pihak ibu, yaitu nenek. Jika nenek tidak mampu menjadi orang tua pengganti, peran tersebut akan digantikan oleh kerabat perempuan yang lain (Sijapati, 2015).

Keputusan melakukan migrasi juga ditentukan oleh kecukupan informasi yang diterima. 
Semakin positif informasi yang diterima, semakin kuat intensi atau niatan untuk melakukan migrasi. Para responden pada penelitian ini pada umumnya tidak hanya mendapatkan informasi dari satu sumber. Agen penyalur tenaga kerja merupakan sumber informasi utama responden (46,7\%). Selain agen penyalur tenaga kerja, teman dan saudara juga menjadi sumber informasi utama dengan persentase masing-masing $42,6 \%$ dan $41,1 \%$. Para agen (makelar) menjadi sumber informasi yang efektif karena menghubungkan calon PMI dengan PPTKIS. Selain itu, para agen tersebut pada umumnya juga berdomisili di desa setempat sehingga mudah dipercaya calon PMI dan keluarganya. Upaya untuk menarik minat para calon PMI, para agen memberikan gambaran besaran gaji yang akan diterima serta kisah sukses beberapa pekerja yang telah berangkat (Munandar, 2013).

Faktor ekonomi merupakan motivasi yang paling banyak dinyatakan oleh responden ketika memutuskan melakukan migrasi. Oleh karenanya, penelitian ini juga akan membahas rencana pemanfaatan remitan. Para responden mengungkapkan bahwa remitan yang akan dikirimkan ke keluarga nantinya tidak hanya digunakan untuk pemenuhan beberapa kebutuhan. Temuan menarik dari penelitian ini ada- lah sebagian besar responden menyatakan akan menggunakan remitan untuk kegiatan yang lebih produktif dan memberikan dampak jangka panjang, seperti biaya pendidikan anak $(88,8 \%)$, modal usaha $(81,7 \%)$, serta tabungan $(77,7 \%)$. Hal ini kemungkinan disebabkan karena bekerja di luar negeri bukan merupakan satu -satunya sumber pendapatan keluarga. Hal tersebut sejalan dengan penelitian oleh Eversole \& Shaw (2010) yang menemukan bahwa sekitar $53 \%$ keluarga migran memiliki satu sumber pendapatan di luar remitan, sementara $28 \%$ memiliki lebih dari dua sumber pendapatan. Oleh karenanya, kebutuhan sehari-hari masih dapat tercukupi melalui sumber pendapatan tersebut.

\section{Faktor pengambilan keputusan menjadi pekerja migran}

Pengujian chi square terhadap faktor yang berhubungan dengan pengambilan keputusan menjadi pekerja migran menunjukkan bahwa terdapat tiga faktor yang terbukti secara signifikan, yaitu pendapatan sebelumnya, posisi sebagai kepala rumah tangga, pendapatan, dan proses pengambilan keputusan. Secara lebih lengkap, hasil pengujian faktor pengambilan keputusan menjadi pekerja migran ditampilkan pada Tabel 2 .

Tabel 2.

Pengujian Faktor Pengambilan Keputusan Menjadi Pekerja Migran

\begin{tabular}{lrc}
\hline \multicolumn{1}{c}{ Variabel } & $\chi^{2}$ & $\boldsymbol{\rho}$ \\
\hline Usia & 7,943 & 0,634 \\
Pendidikan & 4,868 & 0,432 \\
Status Perkawinan & 15,874 & 0,103 \\
Pekerjaan Sebelumnya & 19,175 & 0,206 \\
Pendapatan Sebelumnya & 52,782 & 0,000 \\
Pengalaman Bekerja Migran Sebelumnya & 12,205 & 0,272 \\
Posisi Sebagai Kepala Rumah Tangga & 13,581 & 0,019 \\
Proses Pengambilan Keputusan & 26,421 & 0,003 \\
Usia Suami & 15,723 & 0,108 \\
Pendidikan Suami & 9,168 & 0,516 \\
Pendapatan Suami & 2,283 & 0,684 \\
Pekerjaan Suami & 6,678 & 0,966 \\
\hline
\end{tabular}


Sebagian besar responden bukan sebagai kepala rumah tangga dan diantara kelompok tersebut ekonomi merupakan faktor utama pengambilan keputusan menjadi pekerja migran. Kondisi yang sama juga ditemukan pada kelompok kepala rumah tangga. Faktor ekonomi merupakan faktor yang paling banyak dipilih oleh responden kelompok tersebut. Namun demikian, terdapat faktor lain yaitu keinginan mendapatkan pengalaman baru.

Besarnya pendapatan sebelumnya juga menjadi faktor yang menentukan pengambilan keputusan menjadi pekerja migran. Sebagian besar responden sebelumnya memiliki penghasilan di bawah Upah Minimum Kabupaten (UMK) dan faktor ekonomi melandasi sebagian besar responden di kelompok tersebut ketika memutuskan menjadi pekerja migran. Besarnya pendapatan oleh para responden disebabkan oleh jenis pekerjaan yang dilakukan. Sebagian besar responden bekerja sebagai ibu rumah tangga dengan tanpa penghasilan sama sekali. Temuan penelitian ini selaras dengan penelitian oleh Khusna (2018) bahwa rendahnya pendapatan juga menjadi alasan menjadi pekerja mi- gran perempuan. Subjek penelitian yang sebagian besar ibu rumah tangga dengan tingkat pendidikan rendah cenderung mengalami kesulitan untuk mencari pekerjaan di daerah asal. Persyaratan serta proses pengurusan menjadi pekerja migran yang cenderung mudah serta biaya yang bisa dicicil menjadikan bekerja di luar negeri sebagai pilihan yang diambil.

Proses pengambilan keputusan juga menentukan faktor pengambilan keputusan pekerja migran. Sebagian besar responden melibatkan keluarga inti dalam mengambil keputusan menjadi pekerja migran. responden yang melibatkan keluarga besar dalam pengambilan keputusan terdorong oleh faktor mencari pengalaman baru. Sementara itu, responden yang mengambil keputusan dengan keluarga inti terdorong oleh faktor ekonomi (mendapatkan penghasilan) dan responden yang mengambil keputusan secara individu terdorong oleh faktor ketidaktersediaan pekerjaan di daerah asal. Selanjutnya kedekatan faktor pengambilan keputusan dan faktor alasan ditampilkan dalam diagram analisis korespondensi (Gambar 1).

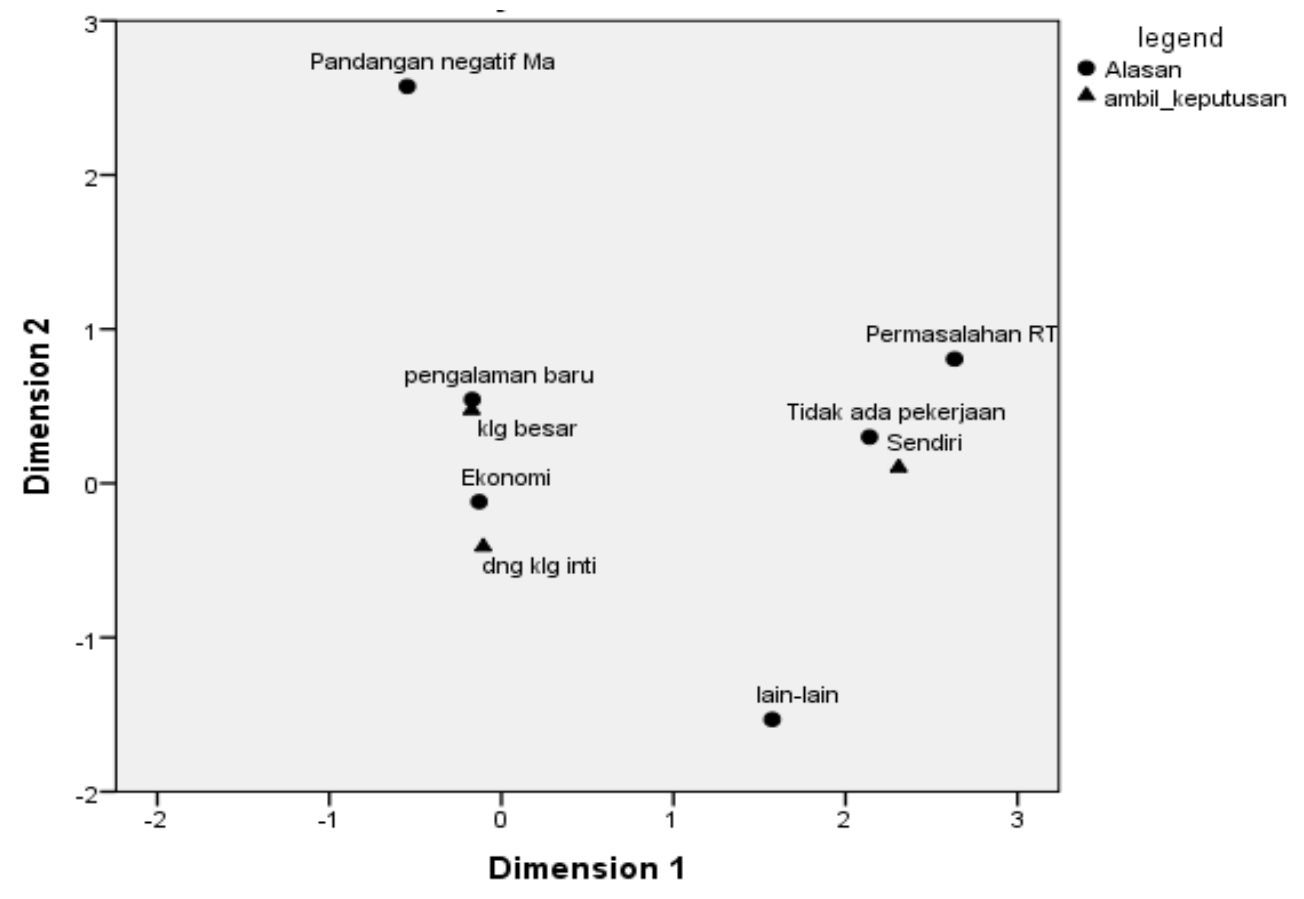

Gambar 1.

Hubungan Alasan menjadi PMI dengan Pengambilan Keputusan 


\section{Faktor Pemilihan Negara Tujuan Migrasi}

Pengujian chi-square terhadap faktor pemilihan negara tujuan migrasi menunjukkan hasil bahwa terdapat lima faktor yang berkorelasi secara signifikan dalam pemilihan negara tujuan migrasi, yaitu usia responden dan suami, pekerjaan sebelumnya, pendapatan sebelumnya, serta alasan memilih negara tujuan. Secara lebih terperinci hasil analisis bivariat pengujian faktor pemilihan negara tujuan migrasi ditampilkan pada Tabel 3.

Usia responden berhubungan secara signifikan dengan pemilihan negara tujuan migrasi. Negara Hongkong banyak diminati oleh responden dengan rentang usia 21-30 tahun, sedangkan Negara Singapura banyak diminati oleh responden dengan rentang usia 3140 tahun. Adapun negara Taiwan diminati oleh responden kelompok rentang usia 21-30 tahun dan kelompok 31-40 tahun. Namun demikian, kecenderungan responden kelompok rentang usia 21-30 tahun lebih tinggi dibandingkan kelompok usia 31-40 tahun. Negara Hongkong banyak dipilih oleh para responden kemungkinan dikarenakan gaji yang diberikan oleh negara tersebut cukup besar. Selain itu, para pekerja migran di negara tersebut memiliki waktu libur di hari minggu yang dapat digunakan untuk berkumpul dengan para pekerja migran dari Indonesia maupun negara lain untuk mencari hiburan. Hal ini lah yang menjadi alasan pemilihan Hongkong oleh para calon pekerja migran yang berusia lebih muda. Negara Taiwan lebih banyak diminati oleh responden kelompok usia 31-40 tahun. Hal ini berkaitan dengan tingginya gaji yang ditawarkan di negara tersebut. Taiwan juga merupakan salah satu negara dengan sistem perlindungan tenaga kerja yang baik, serta fasilitas yang cukup memadai sehingga para pekerja migran mempunyai kesempatan untuk mengembangkan diri selama bekerja di negara tersebut.

Pengujian bivariat menunjukkan bahwa pekerjaaan sebelumnya berkorelasi signifikan dengan pemilihan negara tujuan migrasi. Negara Taiwan cenderung dipilih oleh responden yang sebelumnya bekerja di sektor swasta. Sementara itu, responden yang sebelumnya bekerja sebagai ibu rumah tangga cenderung memilih Negara Hongkong. Adapun Negara Singapura lebih dipilih oleh responden dengan pekerjaan terdahulu sebagai ibu rumah tangga dibandingkan responden dengan pekerjaan terdahulu swasta atau wiraswasta.

Tabel 3.

Faktor Pemilihan Negara Tujuan Migrasi

\begin{tabular}{lrc}
\hline \multicolumn{1}{c}{ Variabel } & \multicolumn{1}{c}{$\chi^{2}$} & $\boldsymbol{\rho}$ \\
\hline Alasan Pemilihan Negara & 74,268 & 0,000 \\
Usia & 22,103 & 0,001 \\
Pendidikan & 7,121 & 0,068 \\
Status Perkawinan & 4,988 & 0,545 \\
Pekerjaan Sebelumnya & 45,128 & 0,000 \\
Pendapatan Sebelumnya & 19,648 & 0,003 \\
Pengalaman Bekerja Migran Sebelumnya & 8,060 & 0,234 \\
Posisi Sebagai Kepala Rumah Tangga & 2,878 & 0,411 \\
Proses Pengambilan Keputusan & 2,244 & 0,896 \\
Usia Suami & 20,258 & 0,002 \\
Pendidikan Suami & 2,163 & 0,904 \\
Pendapatan Suami & 4,998 & 0,172 \\
Pekerjaan Suami & 7,853 & 0,549 \\
\hline
\end{tabular}




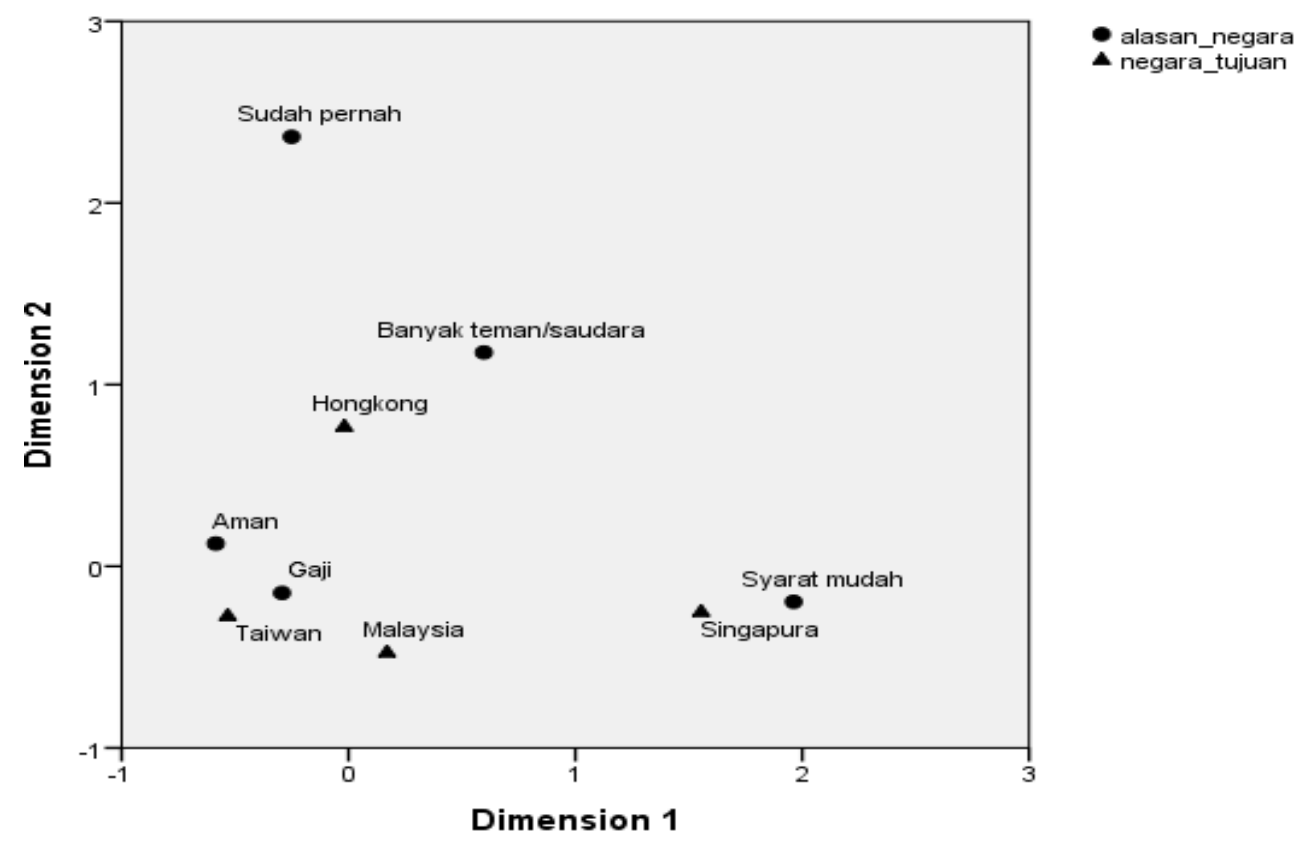

Gambar 2.

Hubungan Alasan Pemilihan Negara dan Negara Tujuan Migrasi

Faktor pendapatan sebelumnya juga berhubungan dengan pemilihan negara tujuan. Responden yang memiliki jumlah pendapatan sebelumnya di bawah UMK cenderung memilih negara Taiwan, Hongkong, dan Singapura.

Alasan pemilihan negara berhubungan secara signifikan dengan negara tujuan migrasi. Sebanyak 66,5\% responden memilih negara karena alasan gaji yang tinggi. Selain gaji, persyaratan yang mudah serta faktor keamanan juga berkorelasi dengan pemilihan negara tujuan dengan persentase masing-masing $11,7 \%$ dan $10,2 \%$. Berdasarkan grafik analisis korespondensi dapat dinyatakan bahwa responden memilih Taiwan sebagai negara tujuan berdasarkan alasan keamanan yang lebih baik serta gaji yang lebih tinggi (Gambar 2). Negara Taiwan relatif memiliki standar gaji yang lebih tinggi dan sistem perlindungan pekerja yang lebih baik dibandingkan negara lain (Susilo, 2016). Kondisi tersebut yang kemungkinan membuat Taiwan menjadi negara tujuan favorit para calon pekerja migran. Sementara itu, Hongkong dipilih responden karena mereka memiliki teman atau saudara yang telah bekerja di negara tersebut. Adapun negara Singapura dipilih karena menurut responden persyaratan bekerja di negara tersebut relatif lebih mudah.

\section{KESIMPULAN}

Pengambilan keputusan pada calon PMI perempuan di Kabupaten Pati tidak hanya dipengaruhi oleh satu faktor tunggal. Namun demikian, faktor ekonomi merupakan alasan utama yang mendasari keputusan bekerja di luar negeri. Keputusan menjadi pekerja migran pada umumnya diambil bersama dengan keluarga terutama keluarga inti (suami dan anak). Selanjutnya berkaitan dengan remitan, para responden lebih memilih mengalokasikan remitan untuk kegiatan konsumtif berdampak jangka panjang, seperti pendidikan anak dan pembelian properti. Faktor yang berhubungan dengan pengambilan keputusan menjadi pekerja migran adalah posisi sebagai kepala rumah tangga, pendapatan sebelumnya, dan proses pengambilan keputusan. Taiwan merupakan negara tujuan favorit para calon PMI perempuan disusul dengan Hongkong, dan Singapura. Adapun alasan utama pemilihan negara tujuan migran adalah gaji yang tinggi, persyaratan yang mudah dan faktor keamanan. Faktor yang berhubungan dengan pemilihan negara tujuan migrasi adalah alasan pemilihan negara, usia, pekerjaan sebelumnya, pendapatan sebelumya, dan usia suami. 


\section{DAFTAR PUSTAKA}

Aeni, N. (2011). Perbedaan Kecerdasan Emosi dan Perlilaku Agresi pada Anak yang Ditinggal Ibu sebagai TKW dengan Anak yang Tinggal Bersama Ibunya (Studi pada Sekolah Dasar di Kecamatan Gabus, Kabupaten Pati Jawa Tengah). Widyariset, 14 (1), 231-240. http://dx.doi.org/10.14203/ widyariset.14.1.2011.231-239.

Aeni, N. (2017). Eksistensi Buruh Migran Perempuan dan Gambaran Kemiskinan Kabupaten Pati. Jurnal LItbang: Media Informasi Pengembangan Penelitian dan IPTEK, 13(2), 139-148.

Asriani, D. D., \& Amalia, E. (2016). Jejak Perempuan Buruh Migran dalam Masyarakat ASEAN 2015. Jurnal Ilmu Sosial Dan Ilmu Politik, 18(2), 147. https://doi.org/ 10.22146/jsp.13129.

Bank Indonesia. (2018). Laporan Perekonomian Indonesia 2018. Jakarta.

Barai, M. K. (2012). Development Dynamics of Remittances in Bangladesh. SAGE Open, 2 (1), 1-13. https://doi.org/10.1177/ 2158244012439073.

BNP2TKI. (2019). Data Penempatan dan Perlindungan PMI. Jakarta. Retrieved from http://portal.bnp2tki.go.id/uploads/data/ data_12-03-2019_094615_Laporan _Pengolahan_Data_BNP2TKI_2018.pdf

Chan, C. (2014). Gendered Morality and Development Narratives: The Case of Female Labor Migration from Indonesia. Sustainability, 6(10), 6949-6972. https:// doi.org/10.3390/su6106949.

Chen, M. A. (2011). Recognizing Domestic Workers, Regulating Domestic Work: Conceptual, Measurement, and Regulatory challenges. Canadian Journal of Women and the Law, 23(1), 167-184. https:// doi.org/10.3138/cjwl.23.1.167.

De Haas, H. (2010). Migration and Development: A Theoretical Perspective. International Migration Review, 44(1), 227-264. https://doi.org/10.1111/j.17477379.2009.00804.x.
De Jong, G. F., \& Fawcett, J. T. (1981). Motivations for Migration: An Assessment and a Value-Expectancy Research Model. Migration Decision Making. New York: New York Pergamon. https://doi.org/10.1016/b978 -0-08-026305-2.50008-5

Dibyantoro, B., \& Alie, M. M. (2014). Pola Penggunaan Remitan Tenaga Kerja Indonesia (TKI) Serta Pengaruhnya Terhadap Perkembangan Daerah Asal. Jurnal Teknik PWK, 3(2), 319-332.

Eversole, R., \& Shaw, J. (2010). Remittance Flows and Their Use in Households: A Comparative Study of Sri Lanka, Indonesia and The Philippines. Asian and Pacific Migration Journal, 19(2), 175-202. https:// doi.org/10.1177/011719681001900201.

Guha, P. (2013). Macroeconomic Effects of International Remittances: The Case of Developing Economies. Economic Modelling, 33, 292-305. https://doi.org/10.1016/ j.econmod.2013.04.016.

Hagen-Zanker, J. (2008). Why Do People Migrate? A Review of the Theoretical Literature (No. 002). MGSoG/2008/WP002. https://doi.org/10.2139/ssrn.1105657

Hoang, L. A. (2009). Gender and Agency in Migration Decision Making: Evidence from Vietnam (Asian Research Institute No. 115). Singapore.

Hoang, L. A., Yeoh, B. S. A., \& Wattie, A. M. (2012). Transnational Labour Migration and The Politics of Care in The Southeast Asian family. Geoforum, 43(4), 733-740. https://doi.org/10.1016/ j.geoforum.2011.12.006.

ILO. (2018). ILO Global Estimates on International Migrant Workers. Geneva. Retrieved from https://www.ilo.org/wcmsp5/ groups/public/---dgreports/---dcomm/--publ/documents/publication/ wcms_652001.pdf.

IOM. (2010). Labour Migration from Indonesia, An Overview of Indonesian Migration to Selected Destinations in Asia and the Middle East. Jakarta. 
Iqbal, M., \& Gusman, Y. (2015). Pull and Push Factors of Indonesian Women Migrant Workers from Indramayu (West Java) to Work Abroad. Mediterranean Journal of Social Sciences, 6(5), 167-174. https:// doi.org/10.5901/mjss.2015.v6n5s5p167.

Jong, G. F. De, Root, B. D., Gardner, R. W., Fawcett, J. T., Gardner, R. W., Fawcett, J. T., \& Abad, R. G. (1986). Migration Intentions and Behavior: Decision Making in a Rural Philippine Province. Population and Environment, 8(1/2), 41-62.

Khan, M. A., Khan, A. W., \& Azam, M. (2015). The Role of Migrant Workers Remittances in Fostering Economic Growth. Article in International Journal of Social Economics, 42, 690-705. https://doi.org/10.1108/IJSE11-2013-0255.

Khusna, N. I. (2018). Karakter Demografi, Sosial, dan Ekonomi Tenaga Kerja Wanita (TKW) Kecamatan Sendang Kabupaten Tulungagung. Martabat: Jurnal Perempuan Dan Anak, 2(1), 27-49.

Lee, E. S. (1966). A Theory of Migration. Demography, 3(1), 47-57.https://doi.org/ $10.2307 / 2061645$.

Lokshin, M., Bontch-Osmolovski, M., \& Glinskaya, E. (2010). Work-related Migration and Poverty Reduction in Nepal. Review of Development Economics, 14(2), 323-332. https://doi.org/10.1111/j.14679361.2010.00555.x.

Munandar, M. A. (2013). Karakteristik, Faktor Pendorong dan Dampak Perempuan Menjadi TKW Luar Negeri di Kecamatan Mranggen Kabupaten Demak. Forum Ilmu Sosial, 40(2), 154-166. Retrieved from https://journal.unnes.ac.id/nju/ index.php/FIS/article/view/9241.

Puspitasari, W. I., \& Kusreni, S. (2017). Faktorfaktor yang Mempengaruhi Migrasi Tenaga Kerja ke Luar Negeri Berdasarkan Provinsi di Indonesia. Jurnal Ilmu Ekonomi Terapan, 02(1), 49-64.
Saefuloh, N. A. (2016). Analisis Korespondensi, Alternatif Uji Statistik Penelitian (Hubungan Tingkat Pendidikan dan Penghasilan Orangtua dengan Nilai Raport Matematika Siswa ). Euclid, 3(1), 502-514.

Sijapati, B. (2015). Women's Labour Migration from Asia and the Pacific: Opportunities and Challenges. Issue in Brief, (12).

Sjaastad, L. A. (1962). The Cost and Returns of Human Migration. The Journal of Political Economy, 70(5), 80-93.

Susilo, S. (2016). Beberapa Faktor yang Menentukan TKI dalam Memilih Negara Tujuan Sebagai Tempat Bekerja, Studi di Desa Aryojeding Kabupaten Tulungagung. Jurnal Pendidikan Geografi, 21(2), 38-46. https:// doi.org/10.17977/um017v21i22016p038.

Taylor, J. E. (1999). The New Economics of Labour Migration and The Role of Remittances in the migration process. International Migration, 37(1), 63-88. https:// doi.org/10.1111/1468-2435.00066.

Undang-Undang Nomor 18 Tahun 2017 tentang Perlindungan Pekerja Migran Indonesia.

Wafirotin, K. Z. (2016). Dampak Migrasi Terhadap Kondisi Sosial Ekonomi Keluarga TKI Di Kecamatan Babadan Kabupaten Ponorogo. Ekuilibrium: Jurnal Ilmiah Bidang Ilmu Ekonomi, 8(1), 15-33. https:// doi.org/10.24269/ekuilibrium.v8i1.36.

\section{BIODATA PENULIS}

Nurul Aeni, lahir 24 Agustus 1984 di Blora, Jawa Tengah. Pendidikan Magister Managemen Pembangunan Universitas Van Hall Larenstein, Belanda. Saat ini bekerja sebagai peneliti pada Badan Perencanaan Pembangunan Daerah Kabupaten Pati. 
